健常若年女性における椅子立ち上がり動作を用いた反応時間測定の 信頼性と妥当性および地面反力との関連

\title{
Relationship between Reliability, Validity, and Measurement of Ground-reaction Force of Reaction Time by Employing Sit-to-stand Movement in Healthy Young Women
}

\author{
尾山 裕介 ${ }^{1)}$, 比留間 麗 ${ }^{1)}$ ，小松晃太朗 ${ }^{2}$
}

Yusuke Oyama ${ }^{1)}$, Urara Hiruma ${ }^{1)}$, Kotaro Komatsu ${ }^{2)}$

\begin{abstract}
要旨：本研究では，椅子立ち上がり（sit-to-stand：STS）動作を用いた反応時間測定の信 頼性と妥当性抢よび地面反力との関連性を検討することを目的とした。被験者は健常な若 年女性42名（20.6 0 0. 8歳）を対象とした。敏捷性の測定では，全身反応時間掞よびSTS 反応時間を評価した。STS 動作時の地面反力測定では, 最大值体重比抒よび地面反力立 ち上がり率，足圧中心移動距離について評価した。その結果，STS 反応時間測定の級内 相関係数 (Intraclass correlation coefficient：ICC) は高く, 信頼性が確認された (ICC $(1,1)$ $=0.735)$ 。また, STS 反応時間と全身反応時間に有意な関連が示された $(\mathrm{r}=0.375, \mathrm{P}=$ 0.014）。しかし，地面反力との関連をみたところ，すべての地面反力変数と関連はみられ なかった。以上のことから，STS 反応時間測定の信頼性および妥当性は確認されたもの の，地面反力との関連はみられない可能性が示唆された。
\end{abstract}

キーワード：反応時間，椅子立ち上がり動作，地面反力，転倒予防

\begin{abstract}
This study investigated the reliability and validity of measuring reaction time by employing the sit-to-stand (STS) movement and examined its relationship with groundreaction force. The participants included 42 healthy young women (mean age $20.6 \pm 0.8$ years). Whole body reaction time and STS reaction time as a measure of agility were evaluated. The peak reaction force per body weight, rate of force development and center of pressure moving distance were evaluated to measure ground-reaction force during STS movement. The Intraclass correlation coefficient (ICC) for measuring the STS reaction time was high (ICC $(1,1)=0.735)$, thus confirming the reliability of the measurement. However, a significant relationship was shown between the STS reaction time and whole body reaction time $(\mathrm{r}=0.375, \mathrm{P}=0.014)$. However, when the relationship with the ground-reaction force was examined, no relationship was found with all the ground reaction force variables. These results indicate that the STS reaction time is reliability and validity, it was suggested that there may be no association with the ground reaction force.
\end{abstract}

Key words: reaction time, sit-to-stand movement, ground-reaction force, fall prevention

\footnotetext{
受付日：2021年 7 月19日，採択日：2021年 9 月14日

桐蔭横浜大学スポーツ健康政策学部：テ225-8503 神奈川県横浜市青葉区鉄町1614番地

TEL : 045-974-5839 E-mail : y.oyama@toin.ac.jp

Faculty of Culture and Sport Policy, Toin University of Yokohama

1614 Kuroganecho, Aoba, Yokohama, Kanagawa 225-8503, Japan

桐蔭横浜大学大学院スポーツ科学研究科

Graduate of sport science, Toin University of Yokohama
} 


\section{I 。緒 言}

転倒は様々な外的および内的要因が相互に作用して 生じるとされている。外的要因には生活環境, 内的要 因には身体的要因が関わっており，加龃に伴って内的 要因が大きく影響すると考えられる。内的要因の一つ に加歯令変化に伴う身体機能の低下が挙げられ ${ }^{11}$, 筋力 やバランス能力, 歩行能力, 敏捷性の低下が転倒の危 険因子とされている 学会5) は高齢者に対する運動処方ガイドラインの中で, 筋力およびバランス能力を改善させる運動プログラム が転倒予防に有効であると報告しており，これらの身 体機能に関する評価は欠かせない。

転倒は躓きやスリップといった外乱刺激によって生 じることが多い到。人は転倒しそうになったり，バラ ンスを崩したりした場合，その刺激を認知して身体を 反応させ，状況に応じた姿勢戦略を用いることで転倒 を回避している。敏捷性は，ある刺激に対して身体の 一部をすばやく動かし身体の位置変化や運動方向の変 換を行うための能力 ${ }^{7)}$ とれ，転倒を回避するために 身体を反応させる局面で発揮される。つまり，敏捷性 が低下することで，状況に応じた姿勢戦略を用いるこ とができず，転倒リスクが大きくなると推察される。 田井中ら ${ }^{4)}$ は, 中高齢者において日常生活の転倒リス クと敏捷性の測定である全身反応時間測定に関連があ ると報告している。しかしながら，全身反応時間測定 は光刺激に対して身体を反応させ，できるだけ素早く 床から両足を離地するように跳躍動作を行う必要があ り，虚弱高齢者や低体力者といった対象者には身体へ の負荷が大きいと考えられる。そのため，測定時に怪 我のリスクも想定され, より安全に敏捷性を評価でき る方法を確立する必要がある。

また，敏捷性によって適切な姿勢戦略を用いたとし ても，自分自身の下肢で身体を支えることができなけ れば転倒が発生する可能性がある。転倒には下肢筋力 やバランス能力が関連しており ${ }^{8)}$, 高齢者を対象とし た研究では椅子立ち上がり（sit-to-stand：STS）動作 によってこれらの身体機能が評価されている。特に, STS 動作時の地面反力を測定することで下肢筋力ゃ バランス能力を定量化し，詳細に評価ができると考え られる。これまで, 敏捷性と STS 動作時の地面反力 変数の関連は確認されているものの ${ }^{9)}$, それぞれの身 体機能について別々の測定が行われている。上述した ように，実際の転倒回避の場面を考慮すると「刺激を 認知して身体を反応させる」，「素早く適切な姿勢戦略
を用いる (敏捷性)」，「身体を支持する（下肢筋力）」 といった一連の動きの中で敏捷性と STS 動作時の地 面反力変数を捉える必要がある。

以上のことを踏まえ, 下肢筋力やバランス能力と関 連がある STS 動作を用いた敏捷性の評価を行うため, 本研究では，STS 動作を用いた反応時間測定（STS 反応時間測定）の信頼性と妥当性および地面反力との 関連性を検討することを目的とした。

\section{II. 対象と方法}

\section{1. 対 象}

本研究を基礎的研究と位置づけたこと，女性のほう が転倒リスクが大きい年ことを踏まえて，被験者は健 常な若年女性 42 名（年齢：20.6 0 . 8 歳）を対象とし た。被験者には事前に口頭と文書にて研究の目的およ び測定に関する説明を十分に行い，書面による同意を 得た。本研究は桐蔭横浜大学倫理委員会の承認（承認 番号：I-29）を得て実施した。

\section{2. 全身反応時間測定}

全身反応時間測定には, 全身反応時間測定器（リア クション, T.K.K. 5408, 竹井機器工業株式会社製) を用いて，猪飼ら ${ }^{11)}$ の手法に基づいて実施した。被験 者を圧力の検出できる測定マットの上に膝を軽く曲げ させた状態で立たせた。そして，2 $\mathrm{m}$ 前方の目線の 高さに設置した光刺激発生装置から赤色光による合図 を与え, 光刺激を感じたら素早く跳躍動作を行うこと を指示した。赤色光が発光してから被験者の両足が測 定マットから離地するまでの時間を全身反応時間とし た。測定は 5 試行実施し，最大值と最小值を除いた平 均值を代表值とした。なお，事前に被験者の理解を深 めるために，本試行の前に 2 試行の練習を行った。す べての測定は同一検者が行った。

\section{STS 反応時間測定}

STS 反応時間測定には, 全身反応時間測定器およ び立ち上がりパワー測定器（運動分析動作装置 zaRitz, BM-220，夕ニタ株式会社製）を用いた。被験者を全 身反応時間の測定で使用した測定マットが敷かれた高 さ $40 \mathrm{~cm}$ の椅子に座らせ，立ち上がりパワー測定器の プラットフォーム上に両足を置くように指示した（図 1 )。本測定器はSTS 動作の地面反力から下肢筋力ゃ バランス能力の評価を行うことができることが確認さ れている ${ }^{12,13)}$ 。サンプリング周波数は $80 \mathrm{~Hz}$ とした。STS 


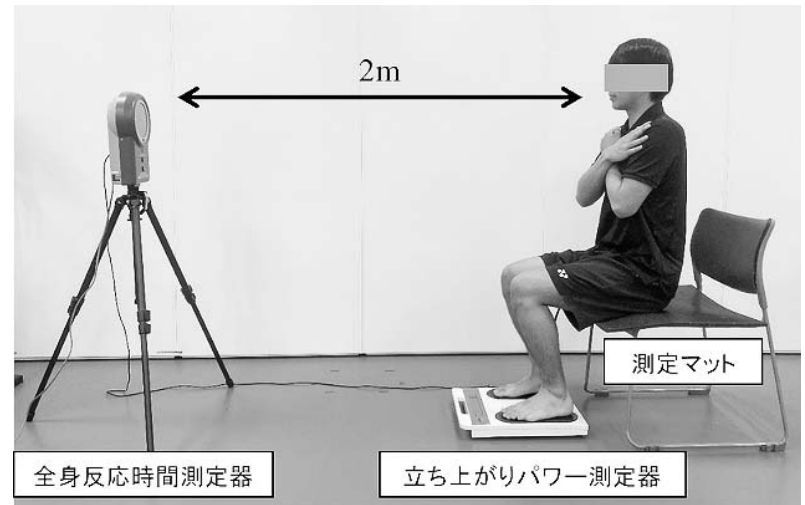

図 1 STS 反応時間測定の開始姿勢

動作時に上肢の反動を使わないように胸の前で腕を組 ませ，膝関節を100～110度屈曲（完全伸展位を０度） に保持した座位姿勢を開始肢位とした。そして，2 m 前方の目線の高さに設置した光刺激発生装置から赤色 光による合図を与え, 光刺激を感じたら最大努力にて 素早く椅子から立ち上がり, その後, 検者の合図で通 常速度による着座動作を行わせた。赤色光が発光して から被験者の臀部が測定マットから離地するまでの時 間をSTS 反応時間とした。これらの起立一着座動作 を 1 試行として，測定は連続して 3 試行実施した。な お，事前に被験者の理解を深めるために，本試行の前 に2 試行の練習を行った。すべての測定は同一検者が 行った。

\section{4. 地面反力变数}

STS 反応時間測定では, 先行研究9,12,13)に基づき, 以下の地面反力の 3 変数を評価した（図 2 ）。

1) 最大值体重比 (Peak reaction force per body weight : $\mathrm{F} / \mathrm{w}$ )

$\mathrm{F} / \mathrm{w}$ は地面反力の最大值を体重で相対化した值で

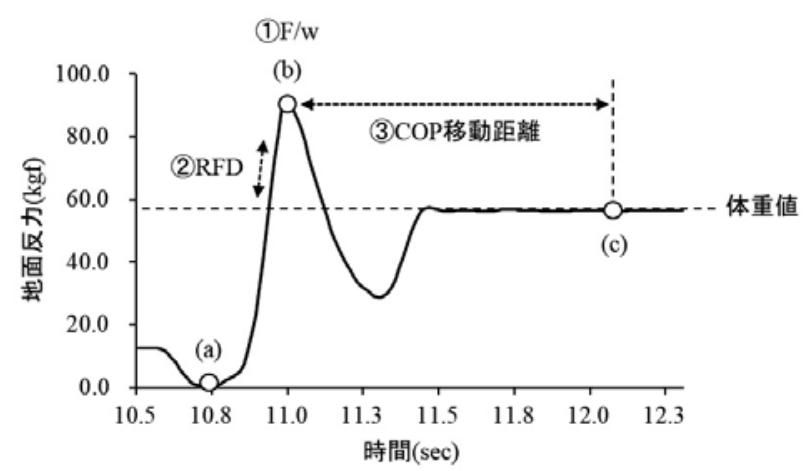

(A) 地面反力の経時的変化

（a）抜重地点，(b) 最大值体重比，（c) 体重值到達地点

図 2 地面反力変数
あり, STS 動作時における鉛直方向の最大の踏み込 みを反映する。 3 試行の平均值を代表值とした。

2) 地面反力立ち上がり率（Rate of force development : RFD)

$\mathrm{RFD}$ は単位時間あたりにおける地面反力の最大増 加量である。本測定器のサンプリング周波数は $80 \mathrm{~Hz}$ であるため，1デー夕間の時間は $12.5 \mathrm{~ms}$ であった。 地面反力の最大増加を記録した 1 デー夕間 $(12.5 \mathrm{~ms})$ およびその前後 3 データ間（37. 5ms）を含む計 7 デー 夕間 $(87.5 \mathrm{~ms})$ の増加量から算出した。筋力発揮開 始時点から筋力上昇時における筋力変化の平均勾配か ら算出した。 3 試行の平均值を代表值とした。

3 ) 足圧中心移動距離 (center of pressure moving distance : COP 移動距離)

COP 移動距離はSTS 動作中における単位軌跡長 $(\mathrm{mm} / \mathrm{sec})$ であり, STS 動作時のバランス能力を反 映する。地面反力の最大值である $\mathrm{F} / \mathrm{w}$ から地面反力 が体重值に到達するまでの区間を用いて算出した。3 試行の平均值を代表值とした。

\section{5. 統計処理}

試行間信頼性を検討するために全身反応時間および STS 反応時間の 3 試行の測定值を用いて級内相関係 数 (Intraclass correlation coefficient : ICC) $(1,1)$ を 算出した。また，STS 反応時間測定の妥当性を検討 するためにSTS 反応時間と全身反応時間の関連性を 検討した。さらに, STS 反応時間と地面反力変数の 関連性を検討した。それぞれの関連性の検討には Pearsonの積率相関係数を算出し，相関分析を行った。

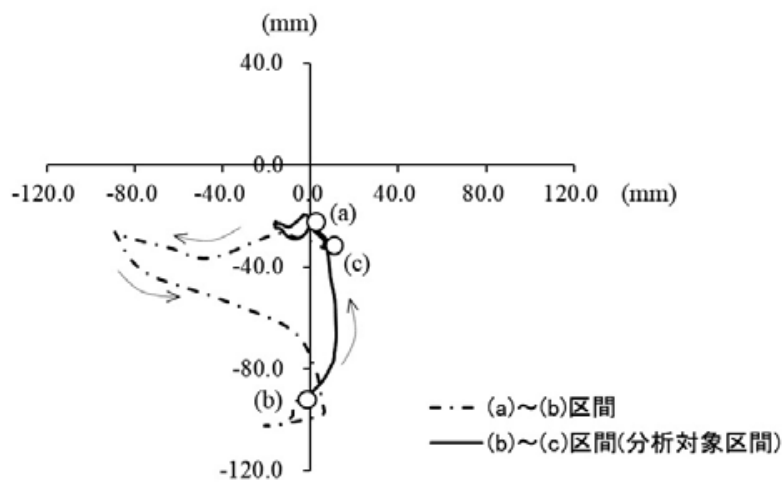

(B) COPの経時的変化

F/w: Peak reaction force per body weight, RFD: Rate of force development, COP: Center of pressure 
いずれの統計処理も有意水準は 5 \%とした。

\section{III. 結 果}

被験者形態掞よび各評価変数の結果を表 1 に示した。 全身反応時間の最大值と最小值を除いた 3 試行の ICC $(1,1)$ は0. 854, STS 反応時間の 3 試行の ICC (1,1)は0.735であった（表 2)。

STS 反応時間と全身反応時間および地面反力変数 との関連について表 3 に示した。STS 反応時間と全 身反応時間は有意な相関関係がみられた $(r=0.375$, $\mathrm{P}=0.014)$ 。しかしながら, 地面反力变数の 3 変数と は有意な相関関係はみられなかった。

\section{IV. 考 察}

信頼性の検討として全身反応時間測定㧍よびSTS 反応時間測定の 3 試行におけるICCを算出したとこ
ろ，全身反応時間測定が 0.854 , STS 反応時間測定が

0.735であった。ICC は同一被験者に複数回測定した ときの測定值がどの程度一致しているかを表す係数で あり，0.7以上で良好とされている ${ }^{14)}$ 。本研究で提案 したSTS 反応時間測定の ICC は 0.7 以上であり，信 頼性の良好な測定方法であると考えられる。また，大 石ら ${ }^{15)}$ は 18 19歳の成人男性における全身反応時間測 定の ICC は0.846と示しており，本研究の全身反応時 間測定の ICC と同程度であった。そのため, 本研究 における対象者の ICC が高く，特別，再現性の高い 集団であった可能性は低いと考えられる。以上のこと から，STS 反応時間測定の信頼性は高いと考えられ るものの，全身反応時間測定のほうが高かったのは 5 試行のうち最大值と最小值を除いた 3 試行の ICCを 算出した影響が大きいと推察される。

妥当性の検討として全身反応時間とSTS 反応時間

表 1 被験者形態および各評価変数の結果

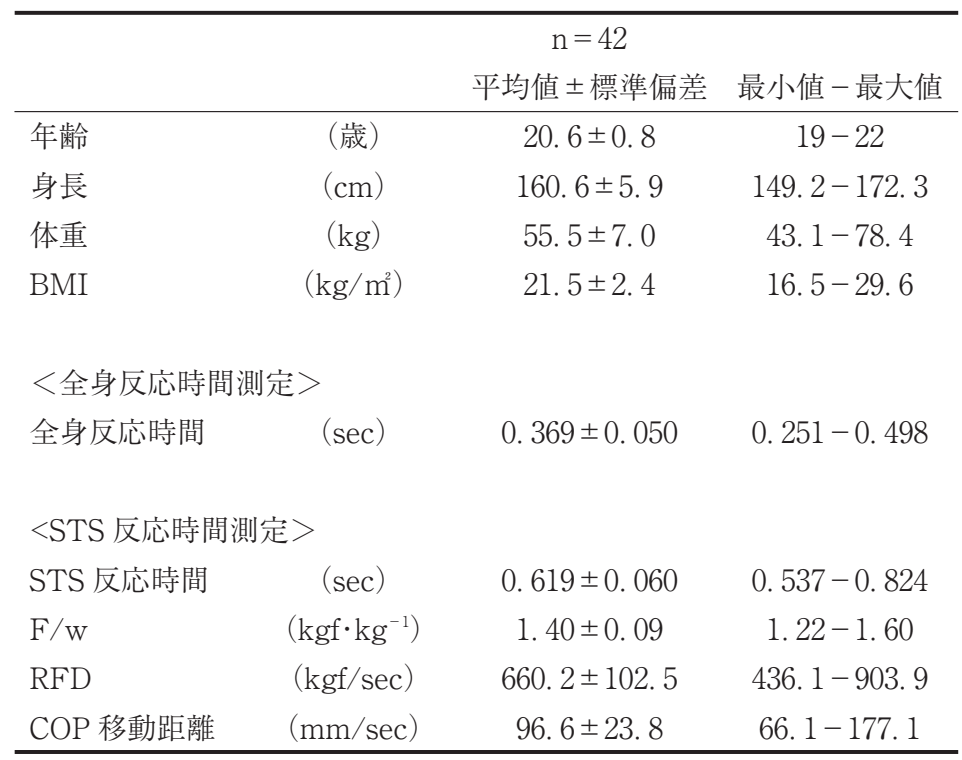

STS: Sit to stand, F/w: Peak reaction force per body weight RFD: Rate of force development, COP: Center of pressure

表 2 全身反応時間と STS 反応時間の級内相関係数

\begin{tabular}{|c|c|c|c|c|c|}
\hline & 1 試行目 & 2 試行目 & 3 試行目 & $\operatorname{ICC}(1,1)$ & $95 \% \mathrm{CI}$ \\
\hline 全身反応時間（sec） & $0.369 \pm 0.055$ & $0.369 \pm 0.051$ & $0.369 \pm 0.051$ & 0.854 & $0.771-0.913$ \\
\hline STS 反応時間（sec） & $0.604 \pm 0.062$ & $0.628 \pm 0.070$ & $0.626 \pm 0.065$ & 0.735 & $0.605-0.836$ \\
\hline
\end{tabular}

表 3 STS 反応時間と各評価変数の相関係数

\begin{tabular}{ccccc}
\hline & 全身反応時間 $(\mathrm{sec})$ & $\mathrm{F} / \mathrm{w}\left(\mathrm{kgf} \cdot \mathrm{kg}^{-1}\right)$ & $\mathrm{RFD}(\mathrm{kgf} / \mathrm{sec})$ & $\mathrm{COP}$ 移動距離 $(\mathrm{mm} / \mathrm{sec})$ \\
\hline STS 反応時間 $(\mathrm{sec})$ & $0.375^{*}$ & 0.134 & 0.163 & 0.014 \\
\hline
\end{tabular}

F/w: Peak reaction force per body weight, RFD: Rate of force development, COP: Center of pressure ${ }^{*} \mathrm{P}<0.05$ 
の相関分析を行ったところ，有意な関連性が示された。 敏捷性は，ある刺激に対して身体の一部をすばやく動 かし身体の位置変化や運動方向の変換を行うための能 力7で，敏捷性を評価するために全身反応時間測定が 実施されている ${ }^{4)}$ 。本研究の結果から跳躍動作が伴う 全身反応時間測定でなくても, 安全性の高い座位姿勢 で実施するSTS 反応時間測定で敏捷性を評価できる 可能性が示唆された。しかしながら, 全身反応時間と STS 反応時間に有意な関連性が示されたものの, 相 関係数は 0.375 と小さかった。一般的に反応時間は, 反応開始時間（刺激発生後から動作開始するまでの時 間）と筋収縮時間（動作開始後から動作終了するまで の時間）に分類される ${ }^{11}$ 。本研究で実施した全身反応 時間やSTS 反応時間の筋収縮時間は動作開始後, 測 定マットから両足または慰部が離地するまでの運動時 間と考えられる。両測定とも単純反応を要することは 共通しているため, 反応開始時間には大きな違いがみ られなかったものの, 両測定の動作様式が異なること から，運動時間において関連がみられなかった可能性 がある。全身反応時間測定では，比較的単純で小さな 動きを伴う跳躍動作であるのに対して, STS 動作反 応時間測定では, 複雑で大きな動きを伴うSTS 動作 である。STS 動作は, 体幹前傾開始から膝関節伸展 開始までの体重移動相, 膝関節伸展開始から体幹後傾 開始までの移行相，体幹後傾開始から動作終了までの 上昇相に分類されるように，身体重心の前後移動およ び上昇が求められる課題である ${ }^{16)}$ 。中でも, 体重移動 相がSTS 反応時間に関連しており，体幹を前方へ傾 斜させる速さや角度の影響が大きく，丸田 ${ }^{177}$ は体幹前 傾角度から 5 つのSTS 動作に類型化しており, 個々 でSTS 動作が異なることを報告している。本研究に おいても，体幹を前方へ傾斜させる速さや角度がSTS 動作の体重移動相に要する時間に影響を与えていたか もしれない。以上のことから，全身反応時間とSTS 反応時間の関連性はみられたものの, その程度は小さ かったと推察される。

地面反力変数は筋力, 起立・歩行能力, 柔軟性, バ ランス能力, 反応性, 巧緻性といった多くの身体機能 と関連し, 中でも RFD が起立・歩行能力, 反応性な ど下肢のダイナミックな動きが求められる身体機能と 強い関連を示すことが報告されている9)。本研究では 反応性である STS 反応時間と地面反力変数の関連を 検討したところ，すべての変数で有意な関連性はみら れず，先行研究9) と異なる結果であった。その要因と
して，STS 動作の開始時における合図の違いが考え られる。先行研究 )では, 検者による合図後, 被験者 の任意のタイミングで STS 動作を開始することがで き，前述した体重移動相（体幹前傾開始から膝関節伸 展開始まで）において体幹を前傾させ，身体重心の前 方移動を伴うSTS 動作であったと推察される。STS 動作は，座位姿勢時の重心位置を前方にある足部の支 持基底面に移動させる必要があるため，体幹を前傾さ せて重心を前方に移動させることで安定したSTS 動 作が可能となる。一方で, 本研究のSTS 反応時間測 定では臂部に測定マットを敷き，光刺激発生による合 図後, 可能な限り素早く立ち上がる課題であったため, 体幹前傾角度が小さくなり体重移動相に打ける身体重 心の前方移動も小さかったと推察される。浅井ら ${ }^{18}$ は 体幹前傾角度を制限したSTS 動作では，通常のSTS 動作に比べて股関節伸展モーメントの減少と膝関節伸 展モーメントの増加が認められたと報告している。ま た，男性健常高齢者に素早い立ち上がりをさせたとき， STS 動作中の股関節モーメントの最大值は支持基底 面である足部に重心が収まっていない時期に生じたこ とが確認されている 時における合図の違いによって, STS 動作が変化す ることで地面反力変数にも影響を及ぼしていたのかも しれない。

本研究の限界として, 第一にSTS 動作時の体幹前 傾角度について客観的に評価できていないことが挙げ られる。体幹を前方へ傾斜させる速さや角度がSTS 反応時間や地面反力変数に影響を及ぼすことを考慮し， ゴニオメーターや 3 次元動作分析装置などの機器を用 いて詳細に分析する必要がある。第二に転倒との関連 を検討できていないことが挙げられる。STS 反応時 間測定は，より安全に簡便な方法で転倒と関連のある 敏捷性を評価できると考えられるものの，本研究では 基礎的研究として健常な若年女性を対象とした。今後 は高齢者を対象に転倒との関連を検討する必要がある。

\section{謝 辞}

本研究を実施するにあたり，測定器をご提供いただ いた株式会社タニ夕開発部の皆さま、ならびに測定に 参加された皆さまに感謝の意を表します。

\section{引用文献}

1)鈴木隆雄：転倒の疫学, 日本老年医学会雑誌，2003，40，85 $-94$. 
2)古名丈人, 島田裕之 : 高齢者の歩行と転倒 - 疫学的調查か らー, バイオメカニズム学会誌, 2006, 30, 132-137.

3)加藤憲人, 黒澤和生 : 足趾が動的姿勢制御に果たす役割に 関する研究, 理学療法科学, 2002, 17, 199-204.

4)田井中幸司, 青木純一郎：在宅高齢女性の転倒経験と体力, 体力科学, 2007, 56, 279-286.

5) Chodzko-Zajko WJ, Proctor DN, Fiatarone Singh MA, et al. : ACSM position stand: Exercise and physical activity for older adults, Med Sci Sports Exer, 2009, 41(7), 1510-1530.

6) Gabell A, Simons MA, Nayak USL : Falls in the healthy elderly, predisposing causes. Ergonomics, 1985, 28, 965-975.

7) 山口宗明, 山田義久, 林田昌子 : 敏捷性の測定方法, 理学 療法, 2005, 22(1), 66-72.

8) Cadore EL, Rodríguez-Mañas L, Sinclair A, et al. : Effects of different exercise interventions on risk of falls, gait ability, and balance in physically frail older adults: a systematic review, Rejuvenation Res, 2013, 16(2), 105-114.

9) 辻大士, 三ッ石泰大, 角田憲治・他：地域在住高齢者を対 象としたSTS 動作時の地面反力と身体機能, 転倒経験, 転 倒不安, 起居移動動作能力との関連性, 体力科学, 2011, 60(4), 387-399.

10)桝本妙子, 山田陽介, 山田実 -他 : 地域在住自立高齢者に おける転倒リスクの関連要因とその性差 亀岡スタディ, 日本公衆衛生雑誌，2015，62(8)，390-401.

11)猪飼道夫, 浅見高明, 芝山秀太郎: 全身反応時間の研究と その応用, Olympia, 1961， 7，210-219.

12) Abe T, Tsuji T, Soma Y, et al. : Composite variable of lower extremity muscle strength and balance ability for evaluating risks of mobility limitation and falls in communitydwelling older adults, Journal of Physical Fitness and Sports Medicine, 2016, 5(3), 257-266.

13) 慎少帥, 藤井啓介, 馬婧宇 ·他 : 要支援 - 要介護高齢者を 対象としたSTS 時の床反力と下肢筋力, 日常生活動作能力 との関連性, 理学療法科学, 2017, 32(6), 881-887.

14) Jackson A, Jackson AS, Bell J : A comparison of alpha and the intraclass reliability coefficients, Research Quarterly for Exercise and Sport, 1980, 51, 568-571.

15)大石健二, 佐藤孝之, 西山哲成 : 幼児の運動能力測定項目 としての全身反応時間の信頼性，体育測定評価研究，2012， 11, 25-33.

16) Millington PJ, Myklebust BM, Shambes GM : Biomechanical analysis of the sit-to-stand motion in elderly persons, Arch Phys Med Rehabil, 1992, 73, 609-617.

17) 丸田和夫：立ち上がり動作時における体幹前傾姿勢の類型 化, 理学療法学, 2004, 19(4), 291-298.

18)浅井葉子, 金子誠喜, 大津慶子：椅子からの立ち上がり動 作における体幹前傾角度と下肢関節モーメントとの関係, 日本保健科学学会誌，2005，8 (1)，51-58.

19）上條史子, 千代丸正志, 大川孝浩・他：高齢者に打ける素 早い立ち上がり後のふらつき要因の検討, 理学療法科 学, 2021, 36(4), 567-572. 